\title{
O barroco e a ordem pós-burguesa: se um extravio na formação do sistema literário brasileiro ${ }^{1}$
}

\author{
The baroque and the post-bourgeois order: \\ if an mistake in the formation of the Brazilian literary system
}

\section{João Guilherme Dayrell ${ }^{2}$}

Resumo: Partiremos da ressalva feita por Haroldo de Campos em "O paradigma aberto", último capítulo de $O$ sequestro do barroco na Formação da literatura brasileira: o caso Gregório de Matos (1986), para destacar dois momentos da obra de Antônio Cândido, quais sejam, Formação da literatura brasileira (1959) e "Dialética da malandragem" (1970). Assim, demonstraremos: 1) a reconfiguração da proposição historiográfica de um sistema literário na passagem de um texto ao outro a partir do trabalho crítico e, 2) os instrumentos que este reposicionamento confere para reduzir o modo de ser nacional à forma de vida de uma classe oprimida, operação originalmente dialética nos estudos literários brasileiros, segundo "Pressupostos, salvo engano, de 'Dialética da malandragem" (1987), de Roberto Schwarz. Doravante, tomaremos origem deste novo sistema, a saber, a sátira barroca de Gregório de Matos, para mostrar seu percurso pela critica e historiografia literária brasileira e especular como sua recepção extraviada, caso se adote a tese de João Adolfo Hansen em A sátira e o engenho (1989), pode conferir um caráter ambíguo às funções do "modo de ser brasileiro" como parte e processo da cena contemporânea.

Palavras-chave: Barroco; ordem pós-burguesa; sistema literário.

Abstract: We will start from the weighting made by Haroldo de Campos in "O paradigma aberto", the last chapter of O sequestro do barroco na Formação da literatura brasileira: o caso Gregório de Matos (1986), to accentuate two moments of Antônio Cândido's work, Formação da literatura brasileira (1959) and "Dialética da malandragem" (1970). Thus, we will demonstrate: 1) the reconfiguration of the historiographical proposition of a literary system in the passage from one text to another, 2) the instruments that this repositioning confers to reduce the brazilian's way of life to the way of being of a oppressed class, originally dialectical operation in Brazilian literary studies, according to "Pressupostos, salvo engano, de 'Dialética da malandragem" (1987), de Roberto Schwarz. Henceforth, we will take the origin of this new system, namely, the baroque satire of Gregório de Matos, to show his path through Brazilian literary criticism and historiography and to speculate as his wrong reception, if the thesis of João Adolfo Hansen is adopted in A sátira e o engenho (1989), can give an ambiguous character to the functions of the "brazilian way of being" as part and process of the contemporary scene.

Key-words: post-bourgeois order; literary system.

A contribuição milionária de todos os erros.

Oswald de Andrade, "Manifesto pau-brasil", 1924.

\footnotetext{
${ }^{1}$ Estas ideias tiveram sua primeira elaboração na forma de texto, precário arquétipo do presente artigo, na ocasião de duas comunicações apresentadas nos EUA, sendo a primeira em Havard e, a segunda, na Boston University, no contexto de uma pesquisa que, até o presente, realizo na USP com o inestimável apoio da FAPESP, instituição a qual agradeço por propiciar excelentes condições de trabalho. Gostaria de deixar, também, um agradecimento aos colegas Maiara Knihs e Rodrigo Lopes de Barros, que me receberam nos EUA.

2 Mestre em literatura pela UFSC; doutor em literatura pela UFMG; pós-doutorando na USP, com apoio da FAPESP.
} 




Menard (acaso sin quererlo) ha enriquecido mediante uma técnica nueva el arte detenido y rudimentario de la lectura: la técnica del anacronismo deliberado y de las atribuciones erróneas.

Jorge Luís Borges, "Pierre Menard, autor del Quijote”, 1939.

Berro pelo aterro, pelo desterro,

berro por seu berro, pelo seu erro.

Caetano Veloso, “Qualquer coisa”, 1975.

1. Um consenso sobre o barroco: a (des) ordem pós-burguesa

Em “O paradigma aberto", último capítulo de seu famigerado ensaio sobre o Sequestro do barroco na formação da literatura brasileira: o caso Gregório de Mattos, publicado em 1986, Haroldo de Campos, em deliberado tom de ressalva, relembra que Antônio Cândido, em “A dialética da malandragem”, estudo de 1970, recolocava o poeta baiano como figura central da literatura brasileira: Gregório de Matos "é agora”, conclui o crítico e poeta concreto, "um dos precursores da comicidade humana 'malandra' em nossa literatura, valorizado, nessa óptica renovada, não pelo veio sério-estético da poesia lírica, amorosa e religiosa, mas pela sátira desabusada" (CAMPOS, 1989, p. 72). Se n'A formação da literatura brasileira, que veio a público, por sua vez, em 1959 - coeva, portanto, à construção de Brasília ${ }^{3}$-, Cândido, segundo a leitura de Campos, adotava um esquema "evolutivo-linear", "épico" e de "encarnação do espírito nacional" para traçar a "estrada real" (CAMPOS, 1989, p. 72) dos momento decisivos da tradição literária brasileira, no ensejo do supracitado estudo sobre o romance Memórias de um sargento de milícias (1854), de Manuel Antônio de Almeida, ao contrário, adotar-se-ia um esquema cíclico ou "mosaical", "constelar", "fraturado", "transtemporal” (CAMPOS, 1989, p. 74-75) que configura, por sua vez, "vias marginais" nas quais, periodicamente, irrompem "expressões rutilantes" (CAMPOS apud CÂNDIDO, 1989, p. 74) como, por exemplo e finalmente, a do poeta barroco ou do referido romancista. Logo, a reinserção de Gregório de Matos, o "primeiro antropófago experimental" (CAMPOS, 1989, p. 75) de nossa poesia, abre

\footnotetext{
${ }^{3}$ Como lembra Thiago Nicodemo, nos anos quarenta o estruturalismo era incipiente na França e as leituras imanentes dominavam nos EUA, Europa e leste europeu, até que Candido, assim como Sergio Buarque de Holanda, "leem Mímesis, de Auerbach, e Literatura europeia e Idade Média Latina do Ernst Robert Curtius" (NICODEMO, 2014, p. 472), inspirando-se, então, para seus respectivos empreendimentos de constituir uma história da literatura. Trata-se, também, especialmente no caso de Cândido, da profissionalização da crítica no país, especialmente em função da criação dos cursos de Letras nas Universidades públicas.
} 

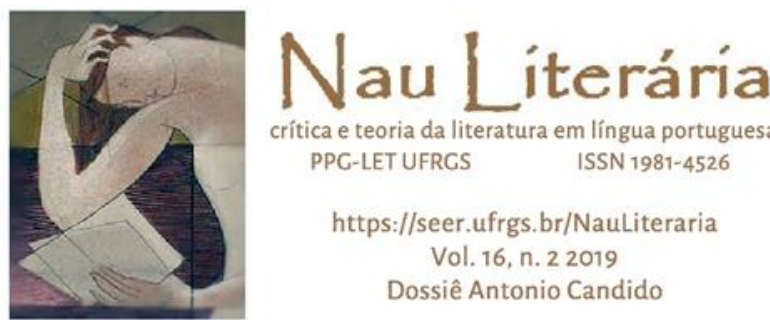

espaço, segundo o poeta tradutor, a uma outra forma de vida, i.e., a modelos de conduta "nãomonológicos", insubmissos aos constrangimentos "da lei (autoritária), da identidade (coesa) e da homogeneidade (excludente do estranho)" (CAMPOS, 1989, p. 74-75), exibindo, por meio da constituição de uma antitradição, "contradições anti-normativas" que "facilitarão nossa entrada num mundo mais aberto" (CÂNDIDO apud CAMPOS, 1989, p. 75), finaliza Haroldo de Campos citando a conclusão de Antônio Cândido acerca da comicidade malandra que deflagra, como dito, na obra Memórias de um sargento de milícias.

Há, de fato, uma mudança de abordagem e, logo, de configuração da tradição literária se comparado os dois referidos momentos do trabalho de Cândido, sendo a presença do barroco especialmente estratégica para a compreensão de cada uma das perspectivas. Embora "tenha permanecido na tradição local da Bahia”, Gregório de Matos, argumenta o estudioso n'A formação, "não existiu literariamente (em perspectiva histórica) até o Romantismo, quando foi redescoberto, sobretudo graças a Varnhagen" (CÂNDIDO, 2009, p. 26), o que caracterizaria sua produção como uma manifestação literária e não Literatura propriamente dita, uma vez que o estabelecimento desta prescinde da constituição de um sistema literário, ou seja, de um conjunto de "obras ligadas por denominadores comuns (como a língua, temas, imagens)" que não apenas "permitem conhecer notas dominantes de uma fase", mas deixam uma descendência, como numa "transmissão de tocha entre corredores." (CÂNDIDO, 2009, p. 25) É igualmente necessário, para tanto, a formação da tríade autor-obra-público, na qual a manifestação das veleidades mais "profundas do indivíduo" (espécie de gesto fundamental e inaugural do literário, ainda que insuficiente para sua plena constituição) se materializa e, posta em conjunto com outras obras, torna-se elemento de "interpretação de diferentes esferas da realidade" (CÂNDIDO, 2009, p. 25) local. O que haveria começado, segundo assinala Cândido, com a figuração do tópico do indianismo na Arcádia mineira, tendo em Cláudio Manuel da Costa o primeiro marco, seguido por Basílio da Gama, Silva Alvarenga e outros, e seu prosseguimento pelo Romantismo - embora o crítico assinale que a produção desta unidade superior, oriunda da "adesão recíproca dos elementos e fatores" (CÂNDIDO, 2009, p. 39), não livre a literatura brasileira de ser "um ramo da portuguesa" (CÂNDIDO, 2009, p. 30).

Tal perspectiva parece se articular sobre um tripé formado pelas abordagens crítica, histórica e teórica que se implicam mutuamente, afinal, Cândido delimita seu objeto (Romantismo) a partir de uma definição do que seria literatura (sistema) indissociável, por sua 

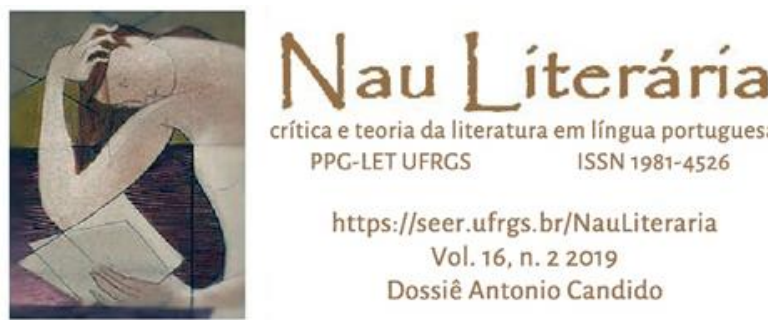

vez, de sua relação com o contexto histórico (interpretação da realidade local). É um projeto distinto, por exemplo, de uma História concisa da literatura brasileira, no qual se cataloga o que de mais importante teria sido feito no Brasil, a começar pela carta do "descobrimento"4. Talvez por isso, quando outra obra se torna objeto de estudo, todas estas articulações são reconfiguradas, como é o caso de "Dialética da malandragem", escrito mais de dez anos depois: aqui, ao analisar o protagonista Leonardo, Cândido nota como não se trata de um pícaro, um servo ingênuo que a "brutalidade da vida (...) vai tornando esperto e sem escrúpulos" (CÂNDIDO, 2010, p. 20), mas um malandro que não procura, por sua vez, "agradar os superiores": vive ao sabor da sorte, mas "nada aprende" (CÂNDIDO, 2010, p. 21) - mesmo porque as ponderações morais estão, em Memórias, por conta do narrador em terceira pessoa, diferentemente do que se passa com o pícaro, locutor de suas próprias desventuras. Oriundo de uma tradição folclórica e arquetípica - como, por exemplo, do imemorial trickster -, correspondendo a uma "certa atmosfera cômica e popularesca" (CÂNDIDO, 2010, p. 22) do Rio joanino - que, como se dá na ação de Memórias, relativiza a separação entre ordem e desordem -, o "primeiro grande malandro que entra na novelística brasileira" (CÂADIDO, 2010, p. 22) torna Memórias um tanto divergente da novelística do seu tempo. Peri seria um exemplo particular, uma vez que "se coíbe até negar as aspirações que poderiam realiza-lo como ser autônomo, numa renúncia que lhe permite construir em compensação um ser alienado, automático, identificado", finaliza o estudioso, "com os padrões ideais da colonização." (CÂNDIDO, 2010, p. 42), fazendo Cândido se lembrar da insurgência de Oswald de Andrade no "Manifesto antropófago", publicado na Revista de Antropofagia (1928), contra o "índio tocheiro. O índio filho de Maria, afilhado de Catarina de Médicis e genro de d. Antônio de Mariz” (ANDRADE apud CÂNDIDO, 2010, p. 43). Em se tratando de Memórias, portanto, não apenas faria pouco sentido falar em "realismo em sentido moderno" (CÂNDIDO, 2010, p. 22), como numa veemente inadequação às "racionalizações ideológicas reinantes (...) na literatura brasileira de então: indianismo, nacionalismo, grandeza do sofrimento, redenção pela dor, pompa do estilo" (CÂNDIDO, 2010, p. 44), ao que arremata o estudioso:

Essa comicidade foge às esferas sancionadas da norma burguesa e vai encontrar a irreverência e a amoralidade de certas expressões populares. Ela se manifesta em Pedro Malasarte no nível folclórico e encontra em Gregório de Matos expressões rutilantes, que reaparecem de modo

\footnotetext{
${ }^{4} C f$. BOSI, 1975.
} 

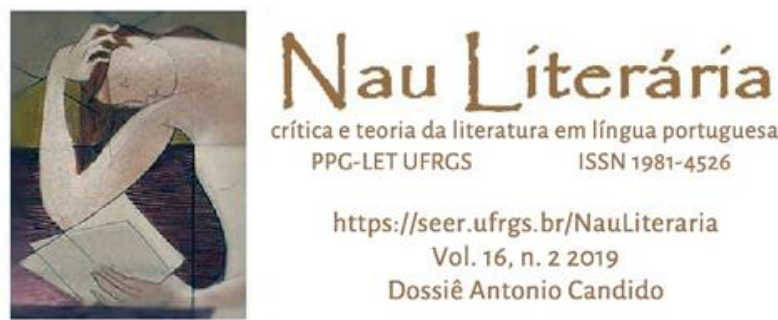

crítica e teoria da literatura em língua portuguesa

PPG-LET UFRCS ISSN 1981-4526

https://seer.ufrgs.br/NauLiteraria

Vol. 16, n. 22019

Dossiê Antonio Candido

periódico, até alcançar no Modernismo as suas expressões máximas, com Macunaíma e Serafim Ponte Grande. (CÂNDIDO, 2010, p. 46)

Se o objeto é o Romantismo, o precursor é a Arcádia; se, ao contrário, é Memórias, quiçá um Macunaíma, a origem, mesmo que estejamos antes no campo das circulares expressões rutilantes que na via recta da transmissão de tochas, é o barroco. Esta nova articulação - poder-se-ia indagar: este novo sistema? - não solicitou somente a ressalva de Haroldo de Campos, como animou um dos mais importantes continuadores do trabalho de Cândido, a saber, Roberto Schwarz. Em "Pressupostos, salvo engano, de 'Dialética da malandragem", o ensaio de Cândido é saudado, ainda que com algum pontual distanciamento: "a reinvindicação da dialética da malandragem contra o espírito do capitalismo talvez seja uma resposta à brutal modernização que estava em curso" quando o texto era escrito. "Entretanto", arremata o crítico, “a repressão desencadeada a partir de 1969 (...) não participava ela também da dialética ordem e desordem?"5 (SCHWARZ, 1989, p. 154) Pontual porque, para o Schwarz, trata-se de um ensaio de grande "originalidade ideológica" justamente por subverter a operação da ideologia ao reduzir o modo de ser nacional à forma de vida de uma classe oprimida em detrimento da dominante, ressaltando, com isto, "os inconvenientes de racismo e fanatismo religioso" que o "modo ser popular nos poupou", além de especular, como continua, "sobre as suas afinidades com uma ordem mundial mais favorável, que pelo contexto do país seria pósburguesa". Esta "sociabilidade desenvolvida pelos homens pobres, à qual o futuro talvez reserve alguma oportunidade" (SCHWARZ, 1989, p. 150) - que Walnice Nogueira Galvão, ao escrever sobre Memórias, chamaria de "estereótipo do brasileiro" (GALVÃO apud CÂNDIDO, 2010, p. 23) em remissão à falta de caráter de um Macunaíma, como lembra Cândido logo na abertura de "Dialética" - alinha aos clássicos de Sérgio Buarque de Holanda ou Gilberto Freyre

\footnotetext{
${ }^{5}$ São raros os pontos argumentativos de Cândido não parafraseados em "Pressupostos", entre os quais o colocado a seguir que, sintomaticamente, parece oferecer um certo norte à supracitada indagação de Schwarz, além de trazer um valioso indicativo do entendimento acerca da função da literatura satírica segundo Cândido: "Um dos maiores esforços das sociedades, através da sua organização e das ideologias que a justificam, é estabelecer a existência objetiva e o valor real de pares antitéticos, entre os quais é preciso escolher, e que significam lícito ou ilícito, verdadeiro ou falso, moral ou imoral, justo ou injusto, esquerda ou direita política e assim por diante. Quanto mais rígida a sociedade, mais definido cada termo e mais apertada a opção. Por isso mesmo desenvolvem-se paralelamente as acomodações de tipo casuístico, que fazem da hipocrisia um pilar da civilização. E uma das grandes funções da literatura satírica, do realismo desmistificador e da análise psicológica é o fato de mostrarem, cada um a seu modo, que os referidos pares são reversíveis, não estanques, e que fora da racionalização ideológica as antinomias convivem num curioso lusco-fusco." (CÂNDIDO, 2010, p. 41) Sobre o receio de Schwarz, cabe ainda notar que, no trabalho sobre Machado de Assis, por exemplo, o branco livre é justamente aquele que está na corda bamba do clientelismo e, para não cair à condição similar a do escravizado, precisa do favor. Logo, é ainda mais radical defensor dos interesses do senhor dono dos meios de produção. $C f$., por exemplo, SCHWARZ, 1987.
} 



da década de trinta ao estudo de Cândido, pois a "dialética ordem e desordem", além de tangenciar o extrato histórico de Memórias, qual seja, o espaço dado exclusivamente à figuração de um setor social da sociedade escravocrata situado num limiar anômico entre os dirigentes e o escravizados, no qual alguns trabalham e outros vivem ao léu; põe em relevo, também, um ethos cultural de um modo de ser brasileiro, isto é, "um traço cultural através do qual nos comparamos a outros países e que em circunstâncias históricas favoráveis poderia nos ajudar" (SCHWARZ, 1989, p. 147). O contorno deste é destacado por Cândido "indicando a linhagem multissecular das obras ligadas a esse aspecto", marcando "sua persistência ao longo das mudanças de estilo (..)" (SCHWARZ, 1989, p. 144). Ora, a origem desta linhagem é corroborada por Schwarz logo na abertura do seu "Pressupostos", sendo encontrável, diz o crítico coincidindo sem resto com seu mestre, "na figura folclórica de Pedro Malazarte, em Gregório de Matos, no humorismo popular, na imprensa cômica e satírica da Regência, no veio de nossa literatura culta do século XIX (....)" (SCHWARZ, 1989, p. 150-151)

Tal é a força deste sistema, sobretudo por ele também ser capaz de revelar uma original forma de vida, que Cândido, diante dele, alça um movimento comparativo em relação a sociabilidade desenvolvida nos EUA, país no qual haveria "grande presença constritora da lei, religiosa e civil" que produz "violência ao estranho" (CÂNDIDO, 1989, 44-45) e maior homogeneidade, ou seja, um modelo de conduta monológico, como quis Haroldo de Campos. Mais religiosa e racialmente plural, como reconheceu Schwarz, o modo barroco de ser brasileiro ganha uma de suas principais formulações, como observa Campos seguindo a indicação de Cândido, em Mário de Andrade que, ainda que "involuntariamente", foi "melhor teórico nacional quando, no rastreio ontológico do 'caráter' do homem brasileiro, chegou não à identidade conclusa, mas à diferença", ou seja, "ao 'descaráter' irresolvido e questionante de seu anti-herói macunaímico" (CAMPOS, 1989, p. 73) - cabe lembrar que, em 1931, na famosa carta aberta a Raimundo Moraes, ao revelar que a cópia havia sido o principal método de composição de Macunaíma, Mário de Andrade confessava: "eu copiei o Brasil, ao menos naquela parte em que me interessava satirizar o Brasil por meio dele mesmo. Mas nem a ideia de satirizar é minha pois já vem desde Gregório de Matos, puxa vida!” (ANDRADE, 1988, p. 427) Aliás, antes de Macunaíma, conforme propõe Haroldo de Campos, o embrião deste barroco descaráter questionador se esboçaria no ensaio "Instinto de nacionalidade", que Machado de Assis conclui em 1873, no qual, ao desmistificar o Romantismo, procedia-se, 

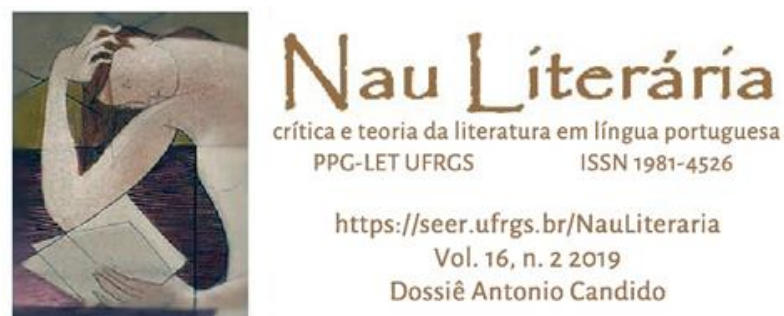

igualmente, um esvaziamento das "pretensões de ubicação localista e de entificação substancialista" da literatura nacional: o que tornaria viável, posteriormente, o "ceticismo agônico" que dá à "última fase da obra machadiana" um aspecto de "carnavalização' do esprit de finesse" (CAMPOS, 1989, p. 74). Associar Machado à Mikhail Bakhtin, lembra o crítico num rodapé, seria apenas a continuação do outrora comprovado vínculo entre literatura do carioca e a "tradição luciânica", da "sátira menipéia" - e, logo, carnavalesca - atestada por Enylton de Sá Rego em sua tese de doutorado de 1984 e que se torna o livro $O$ Calundo e a Panacéia (1989). O que desvincularia o romance machadiano tardio de seus mais proeminentes contemporâneos, a saber, o Romantismo e o Realismo-Naturalismo - sem esquecer do fato que Manuel Antônio de Almeida havia publicado Memórias cerca de um ano antes de Machado se tornar aprendiz de tipógrafo na Tipografia Nacional, da qual era diretor.

Este movimento é também é indicado por Roberto Schwarz quando assinala a passagem efetuada por "Dialética" da crítica de edificação nacional que, como vimos, reduz o nacional à classe dominante, à crítica estética: "da crítica de função puramente local à crítica de sondagem do mundo contemporâneo; da crítica em que o nacional é comemorado à crítica em que ele é historicizado" (SCHWARZ, 1989, p. 136), completa o estudioso. Naquela, onde o nacional existe, ou seja, é um dado e não "processo e parte da cena contemporânea", o crítico dá a entender que estaria a "linha mestra da Formação da literatura brasileira". Este deslocamento de um ao outro, feito por "Dialética", "possui um precursor famoso", uma vez que "Antonio Candido", quando comenta Memórias, "move-se na esteira do ensaio capital de Machado de Assis sobre o 'Instinto de nacionalidade' (1873), que aos assuntos deliberadamente pitorescos do nacionalismo romântico opunha um 'certo sentimento íntimo', que permitiria”, finaliza Schwarz, "ao artista ser de seu tempo e de seu país ainda quando falasse de outros lugares e época" (SCHWARZ, 1989, p. 137). Logo, a identidade brasileira que se constata neste modo de ser cuja origem estaria no barroco seria conflitiva, isto é, um "processo vivo" em suas "infinitas virtualidades embora bem determinado, que se reinventa a qualquer propósito" (SCHWARZ, 1989, p. 137). Se, no entanto, a argumentação de Schwarz nos levaria a incluir Formação na linhagem do nacionalismo pitoresco, imposto de cima, em um debate com Paulo Arantes publicado nas Sequencias brasileiras, em 1999, o crítico retoma a reclamação de um "sequestro do barroco", feita por Haroldo de Campos, para esclarecer que: o termo "formação está sendo usado (...) em sentido sóbrio, e sua normatividade, que existe, é descrita de fora, nos 

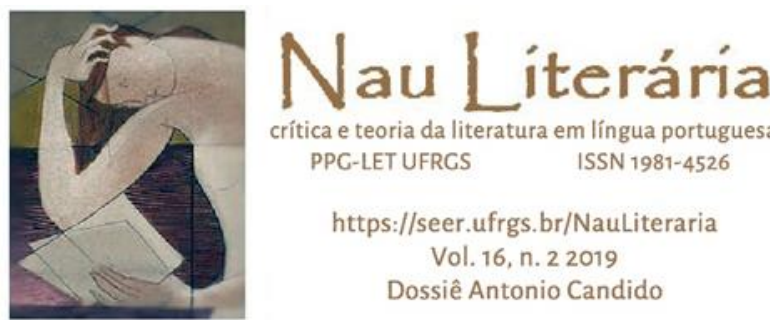

limites de seu desempenho real”, ou seja, sendo internacionalista convicto, Cândido, segundo Schwarz, não adere ao nacionalismo, mas "nota e objeta" não apenas sua formação, que, naquela altura, já era um fato dado, assim como seu "encombrimento ideológico", além de sua “imposição de padrões de classe" (SCHWARZ, 1999, p. 18-19). Ou seja, tratar-se-ia, segundo diz Schwarz alguns anos depois, antes de historicização que de comemoração.

Diferentemente, Campos entende que a escolha do objeto derivava da compreensão do literário, então reduzido, em Formação, à função comunicativa-expressiva da linguagem cujo objetivo é fazer da mensagem veículo transparente, no caso, às veleidades do escritor que, ao serem reunidas, revelam a realidade social local. Com isto, a mensagem em si, ou seja, a informação estética da obra, que seria a função da linguagem mais característica do poético, segundo a leitura que faz do estruturalismo de Roman Jakobson, ficaria em segundo plano. Daí a inadequação do barroco, uma vez que ele seria metalinguístico, lúdico, com larga utilização da inter e da intra textualidade, no qual, diz Campos usando Severo Sarduy, torna-se proeminente a "estética da superabundância", da perda parcial do objeto, em oposição à linguagem "econômica, austera, reduzida à funcionalidade" (CAMPOS, 1989, p. 33) da idade clássica e do Romantismo. O que explicaria a "posição intermediária" dentro de uma série sistemática da literatura nacional atribuída a Manuel Antônio de Almeida na Formação. Porém, no caso de Gregório de Matos, Campos recorre à Presença da literatura brasileira, escrita por Cândido em parceria com José Aderaldo Castello, no qual o poeta seria lido como "monótono na maior parte', com a ressalva do 'pitoresco' e do 'saboroso' nos seus 'melhores momentos”, constituindo uma obra irregular "da qual se salvaria "uma minoria de versos" (CAMPOS, 1989, p. 73). Já em Literatura e sociedade, o barroco seria posto como "vazio e malabarístico" (CÂNDIDO apud CAMPOS, 1989, p. 47), ao passo que Cândido reclama da inexistência de um "autor difícil" em nossa literatura até o Modernismo, havendo, no Brasil, somente a dificuldade do rebuscamento verbal. Ao contrário, argumenta o crítico, a dificuldade engenhosa de Padre Antônio Vieira e Gregório de Mattos teria sua continuidade em Sousândrade, Euclides da Cunha, Augusto de Anjos, e, como diz posteriormente, em João Cabral de Melo Neto.

Todavia, em Formação da literatura brasileira, especificamente sobre o poeta lusobaiano, Cândido comenta que poucos escritores árcades "teriam a rebeldia barroca de Gregório de Matos" (CÂNDIDO, 2009, p. 7), uma vez que eram cidadãos pacatos cuja imitação ou retórica possuía como objetivo apenas limitar o indivíduo "em beneficio da norma” e, para 


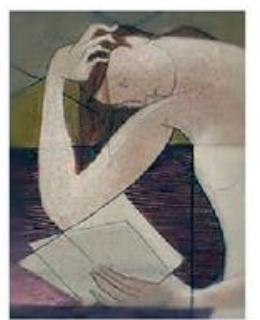

tanto, baniam as "temeridades do engenho" e podavam "na fantasia o estranho e o excêntrico" (CÂNDIDO, 2009, p. 55) ${ }^{6}$. Ao comentar a presença do pitoresco e do nativismo na poesia de Joaquim José da Silva, o estudioso sublinha que sua "veia popularesca, mas de cunho satírico e irreverente", fazia ecoar um "eco longínquo de Gregório de Mattos" (CÂNDIDO, 2009, p. 223). Caberia mencionar, ainda, uma passagem em que o autor comenta sobre a sátira na qual, porém, não há qualquer menção Gregório de Matos: trata-se de uma introdução às Cartas chilenas, quando infere que a "sátira" teria uma "tendência moralizadora muito próxima da que é hoje o jornalismo", preocupando-se somente em "orientar e corrigir, como faz a imprensa moderna" (CÂNDIDO, 2009, p. 161) - ou seja, muito diferente do que infere acerca da sátira barroca, sendo esta, como atestam os exibidos termos de Formação, insubmissa, ousada, engenhosa; e mesmo estranha, excêntrica, fantasiosa, popularesca e irreverente.

De certo que, num post-scriptum de 1987 a Sequestro do barroco, Haroldo de Campos iria ponderar que, em A educação pela noite, Cândido reconheceria determinada "congenialidade" entre a poética barroca e a cultura brasileira devido ao caráter paradoxal, de união de extremos, que caracterizaria ambas. Porém, alguns anos antes disso, para além dos exemplos da própria Formação citado por nós, em "Letras e ideias no período colonial", integrante de Literatura e sociedade, Cândido afirmava que:

Gregório de Matos foi o profano a entrar pela religião adentro com o clamor do pecado, da intemperança, do sarcasmo, nela buscando guia e lenitivo. Ao orador junta-se este poeta repentista e recitador para configurar ao seu modo, e também sob o signo do barroco, a oralidade característica do tempo, que permaneceu tendência-limite no meio baiano até os nossos dias. Apesar de conhecido sobretudo pelas poesias burlescas talvez seja nas religiosas que Gregório alcança a expressão mais alta, manifestando sua obsessão com a morte, tão própria da sua época, porque vem misturada à exuberância carnal e ao humorismo satírico, desbragados e saudáveis. (CÂNDIDO, 2009, p. 102).

Somados tais comentários àqueles que fizemos sobre Formação da literatura brasileira, somos levados a uma conclusão simples, porém de grande importância, qual seja: no que se refere especificamente à avaliação intrínseca ou imanente da poesia de Gregório de Matos, não haveria grandes diferenças entre Cândido - e, por consequência, Roberto Schwarz - e Haroldo

\footnotetext{
${ }^{6}$ Tal rejeição da ousadia faz o século dezoito ser o tempo da psicologia do "homem adulto, branco, civilizado e normal", que reprime "o primitivo" em "estado de natureza"; e que, para tanto, não "desce aos subterrâneos da terra" e não se baixa aos "do espírito". Enfim, justamente neste século acaba estourando, como diz Cândido, Sade, Blake, a Revolução francesa e o Romantismo. Logo, estes estariam do lado, como diz o estudioso, de Gregório de Matos, o qual possuía a "divina maldade", como aquela colocada por Nietzsche, que teria dado um "travo mais saboroso" aos insossos Árcades, segundo as palavras de Cândido (2009, p. 56-57).
} 

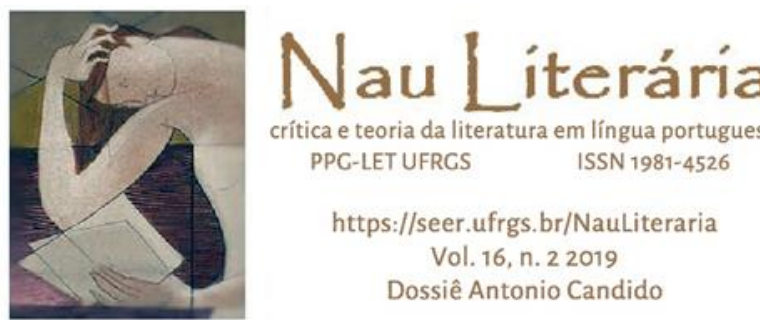

de Campos, ou seja, teríamos em grande medida, nesta camada de leitura, um acordo. O que torna mais nítido o panorama teórico do sequestro do barroco na Formação da literatura brasileira e o reposicionamento de Gregório de Matos em “Dialética da malandragem”: há uma variação do entendimento acerca da natureza geral do objeto literário conforme o recorte que dele de propõe (Romantismo ou Manuel Antônio de Almeida, evolutivo-linear ou cíclicomosaical), porém, a qualificação intrínseca do objeto - no caso, o barroco - não varia de forma decisiva, tornando-se ele apenas mais ou menos pertinente conforme o paradigma de leitura adotado. Dizendo de outro modo: Gregório de Matos é tido por Cândido como ousado, antinormativo, engenhoso, profano, e mesmo estranho, excêntrico, fantasioso, sensual, popularesco e irreverente, tanto na Formação quanto em "Dialética". Excluído num momento, torna-se um notável precursor no outro, no qual suas elencadas características passam a figurar em parcelas decisivas da literatura brasileira do século XIX e do século XX sendo, justamente por isso, reinserido. De resto, a origem do modo de ser malandro e da linhagem não monológica, que apontaria a uma (des) ordem pós-burguesa porvir, segundo Haroldo de Campos, Antônio Cândido e Roberto Schwarz, atende pelo nome de Gregório de Matos. Afinal, a partir de um close reading, de um plano intrínseco da leitura da sua poesia produzida na Bahia dos seiscentos, o que se estabelece é um consenso entre (pós) estruturalistas e dialéticos.

Não que a crítica à Formação não tenha sua razão de $\operatorname{ser}^{7}$, pois é certo que, ao submeter a literatura à ideia de sistema, nem que seja para somente constatar sua existência ou para que ele, como diz Schwarz ao ponderar a objeção, funcione como um "filtro" - afinal, obras "entrelaçadas entre si" e "lastreadas por uma experiência social específica" amortece o efeito ofuscante das novidades dos centros econômicos - que atenua a ilusão universalista da leitura intensificada, por sua vez, pela necessidade de escapar à "estreiteza" da vida cultural de um

\footnotetext{
${ }^{7}$ A necessidade de um conceito que pense a relação das as obras entre si associada a especificidade das experiências sociais é ponto incontornável aos Estudos Literários. A noção de "campo literário", trazida por Pierre Bordieu (1996), tem servido às abordagens preocupadas em pensar a relação da literatura, sua circulação, as relações de poder e as diversas subalternidades, ou seja, não somente de classe, mas relativas à gênero, cor etc. Tais abordagens, especificamente no caso do que se chamou de Estudos Culturais, não necessariamente se alinham aos estudos marxistas ou dialéticos e vice-versa. Não cabe realizar este debate aqui, mas notamos como mesmo Cândido e Schwarz ao tomarem por objeto metodológico a "dialética de forma literária e processo social" (SCHWARZ, 1989, p. 129), onde a divisão do trabalho é posta em relevo, não ignoram o problema do racismo e da religião. Por outro lado, do ponto de vista colonial, como mostrou Franz Fanon $(1968 ; 2008)$ e outros (inclusive, hoje há toda uma gama de marxistas especialmente preocupados em nos relembrar da indissociabilidade entre pensamento e prática liberais da colonização, para a qual é intrínseca a criação das diversas subalternidades, especialmente no que tange a cor), uma coisa não pode ser separada da outra.
} 

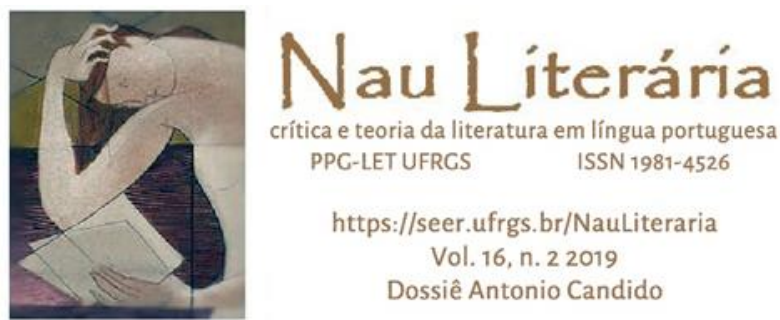

país cuja cultura "funciona a reboque" (SCHWARZ, 1999, p. 20); enfim, ao condicionar a literatura à formação de um sistema, o risco de se subscrever a ideologia é real. Afinal, o setor dominante igualmente possui hegemonia dos meios de produção e circulação da cultura, com maior força para direcionar, segundo seus pressupostos, a conformação da tríade autor-obrapúblico, assim como coordenar a transmissão de tochas. Esta, todavia e como Campos fez questão de ressaltar, não parece ser uma questão de honra para Cândido, afinal, o sistema é, sem grandes preocupações com uma possível incoerência metodológica, não somente inteiramente retraçado diante de uma obra literária que, para ser lida, supostamente assim demandava - mais uma vez: se o objeto é o Romantismo, o precursor é a Arcádia; se Memórias de um sargento de milícias, Gregório de Matos -, mas de sua reformulação surge uma elaboração que transcende a crítica ou teoria da literatura e repousa, o que não é pouca coisa, sobre o modo de ser do brasileiro enquanto possibilidade de um mundo mais favorável e aberto, sobretudo pela sua intrínseca capacidade de subverter a moral racista e fundamentalista do liberalismo burguês. Desprendimento metodológico igualmente extensivo à Roberto Schwarz, que vislumbra nesta reconfiguração do sistema a emergência do ponto de vista das classes subalternas, fazendo-o elevar "Dialética" ao nada trivial status de "o primeiro estudo literário propriamente dialético" - porque não ideológico, observamos - "que seria publicado no Brasil" (SCHWARZ, 1989, p. 129). O que, definitivamente, também não é pouca coisa.

Não dispomos, no momento, dos meios necessários para atestar a centralidade de Memórias de um sargento de milícias nos estudos de literatura brasileira, embora, de uma perspectiva meramente impressionista, a obra não nos pareça, exatamente, um ponto incontornável; assim como, conforme o exibido por Cândido, Gregório de Matos sofre um apagão de quase um século. Todavia, se estas expressões rutilantes ecoaram em Machado de Assis, como certamente se juntaram à poética dos modernistas de São Paulo, o sistema traçado, ainda que por vias marginais, adquire certa centralidade, cuja dimensão não salta aos olhos somente pelo impacto mas, especialmente, pela extensão, afinal, as "obras" Gregório de Matos e Mário de Andrade estão separadas por quase três séculos. O que parece somente se radicalizar se nos restringimos, como nos propomos, à historiografia literária, afinal, este que parecia ser o maior divisor de correntes teórico-metodológicas de nossa vida intelectual ${ }^{8}$, a saber, a leitura

\footnotetext{
${ }^{8}$ Há um resumo sobre este dissenso em SUSSEKIND, 1993.
} 


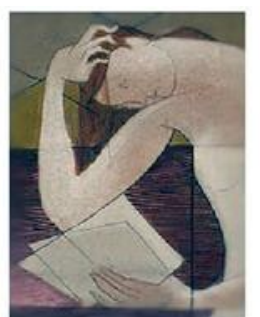

do barroco e o modo pelo qual torna patente as diferenças entre as abordagens extrínsecas e intrínsecas da literatura, que preferem se debruçar, respectivamente, sobre o contexto da obra ou sobre a linguagem; enfim, este ponto central de divergência se mostra, a um olhar mais detido, um espaço de concordância com, inclusive, ares de utopia.

2. Um dissenso sobre o barroco: se um extravio no sistema literário brasileiro

Ainda nos anos oitenta, cerca de três anos após a publicação do libelo de Campos, reivindicando, especialmente, uma revisão da função da sátira, que em Cândido oscilava, por sua vez, entre a normatividade típica do jornalismo e a insubmissão do estranho, João Adolfo Hansen, em A sátira e o engenho: Gregório de Matos e a Bahia do século XVII, argumenta que “(...) traduções brasileiras dos trabalhos de Mikhail Bakhtin sobre a sátira menipéia, o skaz e a paródia, têm hipostasiado a última como gênero supremo da sátira, atribuindo com isso outras virtudes a Gregório." Com isso, confunde-se "paródia' e 'sátira menipéia" e "desloca-se tanto Menipo de Gadara quanto Varrão, nos quais a sátira é simplesmente a mistura de prosa e verso, buscando-se à poesia do século XVII o que possa validar (...) os interesses atuais do intérprete" (HANSEN, 2004, p. 39). Nota-se que, em 1984, numa dissertação de mestrado sobre Grande sertão: veredas, de João Guimarães Rosa, Hansen nega a requisição do barroco como aporte de leitura dos jogos de linguagem do texto - apesar de não citado, este movimento é proposto por M. Cavalcanti Proença em Trilhas no Grande sertão (1958) -, pois eles produziriam uma "língua irreconhecível e fictícia (...) no limite do impossível”, além de indeterminada e insubordinada aos "efeitos de sentido facilmente capturável como metafisíca." (HANSEN, 2000, p. 20) Logo, se a leitura aqui toma a linguagem como objeto, no caso de Gregório de Matos, diferentemente - o que quer dizer, portanto, que a leitura do texto tomando o contexto por base não é um a priori metodológico do estudioso, mas uma necessidade que pode variar conforme as demandas do objeto -, Hansen reivindica um não descolamento da poesia em relação ao plano histórico do qual emerge, qual seja, o da sátira da Contrarreforma composta, por sua vez, por uma "linguagem estereotipada de lugares comuns retóricos poéticos anônimos e coletivizados" (HANSEN, 2004, p. 32). A solicitação pelo poeta baiano dos versos de Camões, Quevedo ou Góngora, com o perdão do óbvio anacronismo, teria, assim, um efeito similar ao da nossa piada, ou seja, engendrar um discurso sem autor e origem que corre de boca 

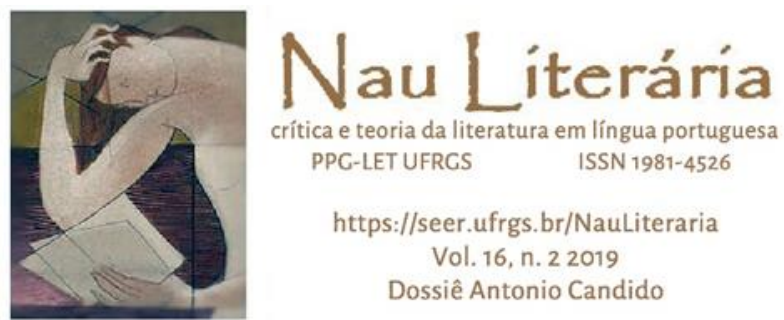

em boca - Gregório de Matos, inclusive, ainda que tenha uma biografia por detrás, seria o nome dado a posteriori a uma série de sonetos dos seiscentos reunidos pelo Licenciado Manuel Pereira Rabelo sob o atestado da moralidade virtuosa, como lembra o crítico.

Todavia, a finalidade destes lugares comuns não seria parodiar outros poetas, marcando uma distância crítica, ou de, através do procedimento intertextual, ser inventivo e esteticamente singular; muito menos confessar uma posição política, expressar um ponto de vista, mas, diferentemente, colocar-se como uma prática que, por meio do uso de dispersões metafóricas, "fusão de conceitos extremos" e exageros, produz estereótipos, caricaturas. Por isso, a intemperança no aspecto formal ou semântico segue a elocução seiscentista simpática aos instrumentos da Santa Inquisição, ou seja, serve de ilustração da irracionalidade das paixões, dos vícios, maus hábitos e das obscenidades que produzem monstros que, a partir do dispositivo retórico, devem ser controlados. É "a teologia-política que rege o bom uso da Republica" no "controle da natureza humana" (HANSEN, 2004, p. 49), no enquadramento do corpo biológico para a produção da alma. Se "na sátira ibérica seiscentistas, mulheres não brancas são, por definição, uma sub-humanidade relegada" à "bestialidade pelos códigos teológicos políticos da Conquista", logo o estilo para "tratá-las deve ser cômico ou baixo" (HANSEN, 2004, p. 90) e, por isso, a sátira é perfeitamente verossímil, em exemplar obediência aos códigos normativos das poéticas gregas e romanas. O soneto "Da cidade", em que Gregório de Matos dizia que "Vós me ensinastes a ser/ das insconstâncias arquivo" (MATOS, 1990, p. 42), exemplificaria esta leitura da sua prática discursiva: "misógina, crítica à simnia, glutoneria, usura (...), critica dos judeus", aos negros, às práticas não heterossexuais, aos sacerdotes e freiras que, por ventura, voltavam-se contra a Igreja, enfim, "o mundo as avessas” da natureza decaída da besta humana é arquivado pelo murmúrio maledicente, pela fofoca desenfreada que os enquadra, reforça seus traços exageradamente e os expõe ao ridículo. Vocábulos ou hábitos dos negros e indígenas, a sexualidade feminina, as necessidades fisiológicas dos homens, enfim, ao serem incorporados aos sonetos ilustram a normatividade da Lei pela demarcação da distancia que estão "do ideal hierárquico de comportamento", ameaçando, assim, de desintegrar o "corpo místico do Estado", ou seja, a unidade cosmopolítica ideal que pressupõe, aristotelicamente, a pluralidade atual, sendo a cabeça racional (como Deus) a comandar as partes baixas do corpo assim como o homem branco europeu o gentio. Não apenas fofoca o tempo inteiro, a persona satírica - muito longe, portanto, de ser um “eu”, mas, antes, um tipo, um gênero discursivo - 

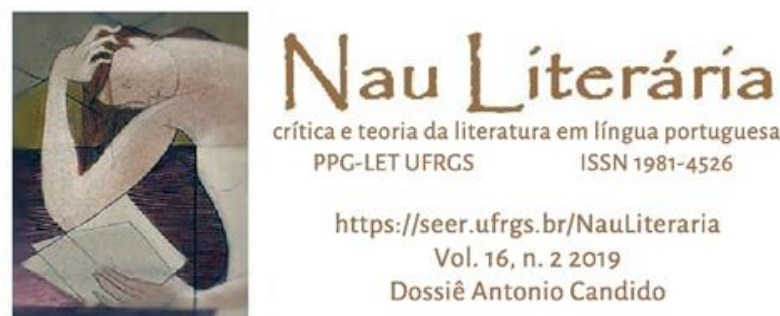

crítica e teoria da literatura em língua portuguesa

PPG-LET UFRCS ISSN 1981-4526

https://seer.ufrgs.br/NauLiteraria

Vol. 16, n. 22019

Dossiê Antonio Candido

também destina encômios ao cidadão de bem, com queria Platão em sua República, especialmente aos governantes e militares, procurando elaborar a limpeza do sangue e da cidade por meio da "catarse", isto é, a "purgação das paixões"9 (HANSEN, 2004, 200) que angaria, finalmente e como quis Aristóteles em sua Poética, a partir da "persuasão que vícios e virtudes teatralizados podem produzir sobre público.” (HANSEN, 2004, p. 49)

De nossa perspectiva, somente aqui estaríamos, de fato, diante de um dissenso sobre o barroco. Todavia, Hansen, ao elencar o que se trataria de uma série de, como diria Jorge Luís Borges, atribuciones erróneas y anacronismos - deliberados? - proferidos desde o século XIX acerca da "poesia dita de Gregório de Matos”, a saber, "pessimismo', 'ressentimento', 'plágio', 'amoralidade', 'realismo', 'oposição nativista crítica', 'antropofagia', 'libertinagem', "revolução" 10 (HANSEN, 2004, p. 33), deixa de fora aquela que, para Schwarz, seria a figura cunhada pelo mestre - que inaugura o estudo dialético de literatura no país e cuja origem deveria ser remetida a Gregório de Matos: a "malandragem”. Em "Barroco, neobarroco e outras ruínas”, estudo de 2001, Hansen dedica uma nota de rodapé à questão levantada em $O$ sequestro do barroco - que, em "Romantismo e Barroco", é qualificado como um "livro nacionalista" (HANSEN, 2013, p. 57) - para esclarecer que Cândido não poderia incluir Gregório de Matos na Formação, pois a Bildung romântica (HANSEN, 2001, p. 16-17), na qual sua empreitada se inspira, toma-o como representação despótica do Regime Antigo, portanto, exterior aos pressupostos - burgueses? - do projeto formativo. Logo, a leitura imanente de Gregório de Matos presente neste e outros textos de Cândido que, décadas depois, iria aflorar como precursora de um ousado e original modo de ser brasileiro, é ignorada. Aliás, "um Gregório de Matos hedonista, em versão freyriana da antropologia doce-bárbara” (HANSEN, 2004, p. 40), seria, para Hansen, tributário à leitura sincrônica proposta pelos poetas concretos, sobretudo quando deglutida "oswaldianamente, via interpretação da Antropofagia Cultural e do Tropicalismo" que leva, finalmente, Caetano Veloso, no disco Transa, de 1972, a repetir os versos do soneto atribuído ao poeta barroco: “Triste Bahia, oh quão dessemelhante” - que já Alfredo Bosi apontava como crítica à incipiente burguesia, indicada, no soneto, pela expressão

\footnotetext{
${ }^{9}$ A catarse é uma figura importante que retornará no muito força no Romantismo ( $C f$. MACHADO, 2006).

${ }^{10}$ Em outro texto, o crítico elenca outro grupo de características erroneamente atribuídas ao barroco: “(...) dualidade, sentido dilemático, gosto pelas oposições, fusionismo, jogo de palavras, acúmulo, excesso, horror do vácuo, desproporção etc. - não passam de generalidades "genéricas" que poderiam ser aplicadas a qualquer outra arte de qualquer outro tempo" (HANSEN, 2004, p. 52).
} 


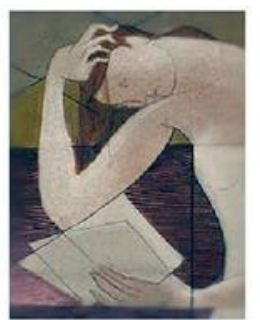

"Máquina mercante"; a partir, contudo, da perspectiva de um monarquista pertencente à nobreza $^{11}$, e não do rebelde que sonha com um mundo pós-burguês. E, embora tais apropriações possam ter validade enquanto inventividade poética, criando, por sua vez, "algum valor de analogia na descrição do experimental da neovanguarda com a agudeza engenhosa, que aproxima e funde conceitos distantes", ela é a-histórica, ou seja, não pode ter, como finaliza Hansen, “a mínima pretensão de interpretação histórica.” (HANSEN, 2004 P. 33)

A sobrevivência da poesia de Gregório de Matos pelos séculos XIX e XX devido a um extravio de leitura, isto é, caso a leitura intrínseca que dela realiza João Adolfo Hansen proceda, como parece ser o caso ${ }^{12}$ - afinal, o estudo, entre outras manifestações da sua exaustividade que não pode, por sua vez, ser ignorada, examina "cem anos das Atas e das Cartas do Senado da Câmara de Salvador" (HANSEN, 2004, p. 24), enquanto outros textos aqui mencionados sequer citam um verso do poeta baiano ${ }^{13}$-, parece-nos, todavia, menos difusa que sistemática. Porque, levando em conta que o mal-entendido também se inscreve no âmago da crítica profissional de abordagem dialética, de profundo protagonismo nos estudos de literatura brasileira, algumas possíveis transmissões de tocha poderiam ser sugeridas. Por exemplo: no segundo tomo da História da literatura brasileira, de 1888, Silvio Romero - lembrado por Hansen - postula Gregório de Matos como "a mais perfeita encarnação do espírito brasileiro, com sua facécia fácil e pronta, seu desprendimento de fórmulas, seu desapego aos grandes, seu riso irônico". Se o poeta era um "discípulo de padres", continua o crítico, logo ele "começa por debicá-los, escarnecer deles e duvidar de sua santidade e sabedoria", ao que conclui: "Matos é um pândego, um precursor dos boêmios, amante de mulatas, desbragados, inconveniente, que tem coragem de atacar bispos e governadores..." (ROMERO, 1960, p. 365) Mas não se trata somente de comportamento, mas - o que muito chama atenção - do início da literatura no Brasil enquanto traço de cor local: "se a alguém no Brasil se pudesse conferir o título de fundador da nossa literatura", finaliza o crítico, "esse deveria ser Gregório de Matos e Guerra. Foi filho do

\footnotetext{
${ }^{11}$ Gregório de Matos, o "filho d'algo em apuros não tolera", conclui o crítico, "o comerciante forâneo nem o desenvolto mercador cristão-novo. O que está em jogo não é uma situação irritada de consciência nacionalista ou baiana, mas uma rija oposição estrutural entre nobreza, que desce, e a mercadoria, que sobe.” (BOSI, 1992, p. 101) ${ }^{12}$ Como, por outro lado, o objeto deste estudo não é a poesia de Gregório de Matos, ou seja, não analisaremos seus sonetos, trataremos a leitura de Hansen como uma possibilidade entre as outras, ainda que a mais verossímil. ${ }^{13}$ Neste sentido, cabe mencionar o estudo formal dos poemas atribuídos a Gregório de Matos em CHOCIAY (1993), cuja conclusão aponta para uma aderência dos poemas ao contexto do qual emanam, no qual, por sua vez, a redondilha maior (heptassilábico) era a metrificação mais usual, salvo as específicas exceções apontadas.
} 

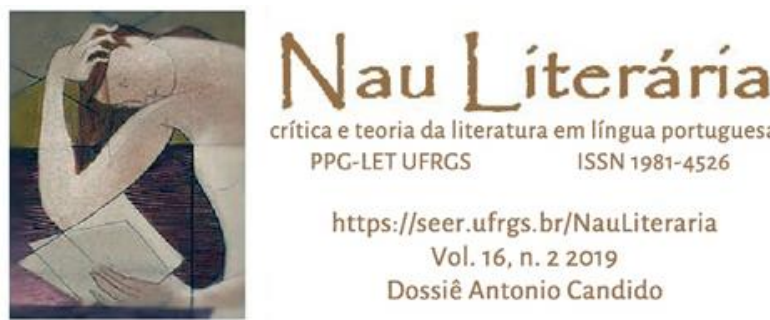

país; teve mais talento poético do que Anchieta; foi mais povo; foi mais desabusado; mais mundano, produziu mais e num sentido mais nacional.” (ROMERO, 1960, p. 373)

Poder-se-ia sugerir, sobretudo considerando que Cândido toma o trabalho de Romero por objeto de sua tese escrita em 1945, ler "Dialética da malandragem" a partir de tais considerações e tendo nelas possível inspiração, o que possivelmente ampliaria a vizinhança do seu ensaio para além dos canônicos estudos da década de trinta, remetendo ao século anterior a junção entre crítica e literária e modo de ser brasileiro. Logo, as vias de um sistema barroco parecem solidamente ligadas pela historiografia, o que nos leva a outra perspectiva da questão: se João Adolfo Hansen, mesmo declarando não se opor à apropriação heurística do barroco, alertou precisamente para o perigo de transferir "as metáforas da ficção ou da prática poética (...) para o discurso crítico e historiográfico", afinal, se a "poesia é sempre histórica (...)", "o discurso da poesia não é o discurso da história” (HANSEN, 2001, p. 16); deveríamos, diferentemente, proceder o alerta contrário, afinal, o caminho seguido pelo barroco parece vir da mão oposta, ou seja, da transferência que a autodeclarada historiografia, ao criar uma ficção, faz à autodeclarada ficção, que a toma como historiografia. Todavia, não há simetria entre coisa e outra, pois, como mesmo se disse, o discurso da poesia não é o da história, assim como sua pretensão documental. Vejamos, por exemplo, o estudo Gregório de Mattos, de 1894, no qual Araripe Jr. propõe que o poeta, branco e estudado, iria ganhar "nova alma" ao chegar no Brasil devido a obnubilação, conceito que tipifica a "transformação por que passavam os colonos atravessando o oceano Atlântico, e na sua posterior adaptação ao meio physico e ao ambiente primitivo" (ARARIPE JR., 1910, p. 37) que os “entonteci e os transformava em selvagens, imitando até mesmo a brutalidade dos indígenas" (ARARIPE JR., 1910, p. 38). Tornando-se mais animal, Gregório difama coisas santas, assim como sua poesia adquire "dois terços, pelo menos, dos vocabulos de origem africana e tupy", além de outros "barbarismos (...) nativos" (ARARIPE JR., 1910, p. 172). Araripe, inclusive, chega a mencionar a hipótese de que a sátira pudesse visar o regramento dos costumes, porém, arremata que, no caso de Gregório de Matos, ela seria a irrupção de uma "irracionalidade" que decompõe "a vida social" (ARARIPE JR., 1910, p. 4), o que o colocava ao lado de um Aristófanes ou Diógenes e distante, por exemplo, François Rabeleais, cujo "riso gaulez", finalmente, não feria em a sociedade.

O livro Catatau, que Paulo Leminski publica em 1975, ilustra um processo muito semelhante: René Descartes, o espírito clássico em pessoa e que realmente serviu ao Conde de 

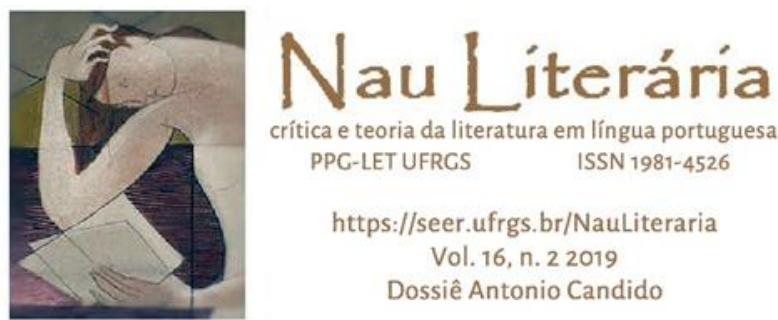

crítica e teoria da literatura em língua portuguesa

PPG-LET UFRCS ISSN 1981-4526

https://seer.ufrgs.br/NauLiteraria

Vol. 16, n. 22019

Dossiê Antonio Candido

Nassau na Holanda, seria convocado para vir ao Brasil e, defronte à fauna e flora brasileira, fuma uma erva dada pelos negros, toma o cauim oferecido pelos indígenas e se vê enredado pela natureza pletórica: "bestas, feras entre flores festas circulam em jaula tripla" (LEMINSKI, 2010, p. 15). Com uma lupa, ele tenta ser um observador temperante e objetivo da natureza que, todavia, obnubila sua racionalidade: "penso mas não compensa" (LEMINSKI, 2010, p. 16), malogra o filósofo. A partir desta espécie de vertigem ontológica, os animais ganham a possibilidade de raciocínio - “um papagaio pegou meu pensamento” (LEMINSKI, 2010, p. 17), reclama o alucinado Cartésius - e a linguagem se torna convulsiva, ruidosa. Não à toa, Haroldo de Campos disse que a aventura de Renato Cartésius neste texto é um sonho "barrocodélico", um cometimento "neobarroco, de um ensaio de liquefação do método e de proliferação das formas em enormidade da palavra" (CAMPOS, 2010, p. 236). Em Catatau se diria: "método duvidoso desses bichos: em-te-vi! Matar para garantir o método: aquele olhar te olhando é pensamento e isso arde" (LEMINKI, 2010, p. 42). Poder-se-ia, inclusive, atribuir algo utópico ao enredo sob a sugestão de inverossimilhança da convivência dionisíaca entre um senhor branco junto aos indígenas, negros aqui trazidos para aqui servirem de mão de obra escravizada e a natureza, objeto da sanha extrativista que exauri a terra: todavia, muito diferente de Araripe Jr., é preciso repetir, o anacronismo aqui é deliberado, ou seja, produz-se, propositalmente, distanciamento, mudando completamente a natureza do lugar de enunciação.

A leitura de Araripe que, assim como de Romero ou Cândido, não se pretendia ficcional ou artística, entretanto, faz escola: José Veríssimo, em sua História da literatura brasileira. De Bento Teixeira (1601) a Machado de Assis (1908), publicada em 1915, cita seu estudo - estando também em contato com Romero - para inferir que o poeta baiano "achou na terra onde expandir seus instintos nativos se não atávicos, influídos de mais a mais pelo meio. Gregório de Matos é a mais perfeita e mais ilustre expressão esse tipo essencialmente nacional, do qual foi e continua a ser”, completa, "a Bahia fecunda progenitora, o capadócio." (VERÍSSIMO, 1954, p. 81) O estudioso entendia a sátira como "bifronte", podendo deixar de tomar o oprimido para eleger o opressor como objeto, embora sempre fosse "obscena" e "petulante", o que viria calhar com a "vida desregrada e ainda torpe" (VERÍSSIMO, 1954, p. 82-84) do poeta.

Diferentemente, numa conferencia ministrada trinta anos depois e intitulada "A sátira na Literatura Brasileira", Oswald de Andrade propõe que, como o riso é desencadeado pelo "insólito, o bizarro, o anormal", a sátira, logo, serve ao "oprimido" que, com ela, "se sente 

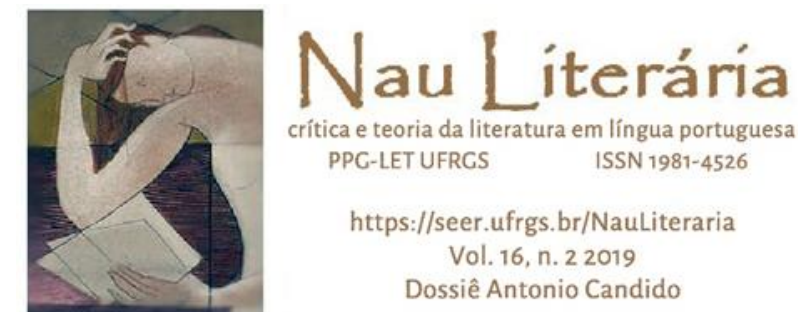

crítica e teoria da literatura em língua portuguesa

PPG-LET UFRCS ISSN 1981-4526

https://seer.ufrgs.br/NauLiteraria

Vol. 16, n. 22019

Dossiê Antonio Candido

justiçador", "vingado"14 (ANDRADE, 1991, p. 70), pois sempre encontra nela "defesa individual ou social contra a opressão." (ANDRADE, 1991, p. 82) Talvez por isso ela seguiu, no Brasil, enquanto tradição subterrânea, então recuperada por Mário de Andrade e Raul Bopp, correndo por debaixo do imperativo do indianismo e encontrando em Gregório de Matos um grande expoente. Repentista satírico notável, pornográfico, desbocado, "possuía pena diabólica (...), cantante e popular" e acaba por indicar "os rumos da literatura nacional" (ANDRADE, 1991, p. 71), conclui Oswald de Andrade. Após o barroco, a sátira reaparece nas Cartas chilenas, segue em suas manifestações mais individualistas no século XIX, até chegar ao século XX com o próprio Oswald, não apenas no semanário "O pirralho", que criou com outros intelectuais, como também em sua produção poética, sobre a qual faz questão de citar o teatro, mais especificamente, a peça "Panorama do fascismo", sobre a qual explica: é uma "sátira contra o fascismo, que julgo mais que oportuna, pois hoje o fascismo não anda às claras como em 37, quando a publiquei, mas parece oculto e camuflado nas roupagens mais inesperadas" (ANDRADE, 1991, p. 82). Alguns anos depois, em "A marcha das utopias", de 1953, Oswald declarava que: "Resta uma palavra sobre o barroco. O estilo utópico. Nasceu com a América. Com a Descoberta. Com a Utopia. Ninguém me convencerá de que no Barroco há uma descendência direta do Renascimento. Nego a Bernini”, continua, "o direito de se colocar com seus lençóis na herança duma plástica vinda do mundo colonial que se abria entre flores, lianas e frutos disformes. O Grego, sim. É Barroco.” (ANDRADE, 1991, p. 298)

Assim, proliferaram conceitos para o barroco ser trazido à ordem do dia. À utopia, malandragem ou obnubilação, entre muitos outros, Silviano Santiago, ao abordar a literatura dos anos setenta, destacava o protagonismo da "curtição", na qual se privilegia "a comunicação não-verbal e a des/ordem", prefere-se o som ao sentido (pensa-se na dispersão gráfica e no silêncio de Mallarmé), o gozo e o "prazer estético" à leitura (juízo?), imperando o fragmentário, marca de "Machado de Assis, de Oswald de Andrade, um pouco mais longe, de Nietzsche" (SANTIAGO, 2000, p. 130-131) Aqui, o nome de Gregório de Matos é evocado por sugestão dos próprios escritores, sendo somente constatado pelo crítico que, então, está lendo Urubu rei,

\footnotetext{
${ }^{14}$ No que tange a lírica, é muito interessante notar o caso de Luiz Gama, poeta que retoma a sátira, inclusive citando Gregório de Matos, e a direciona claramente contra o opressor - também advogado negro e militante, Gama liberta um grande número de escravizados, sendo uma das mais importantes figuras da luta abolicionista. Sobretudo a partir de Oswald e seu poema piada, a lírica brasileira testemunha, até os dias de hoje, uma presença muito grande do humor e do deboche, cuja relação ou não com o barroco teria que ser mapeada caso a caso.
} 

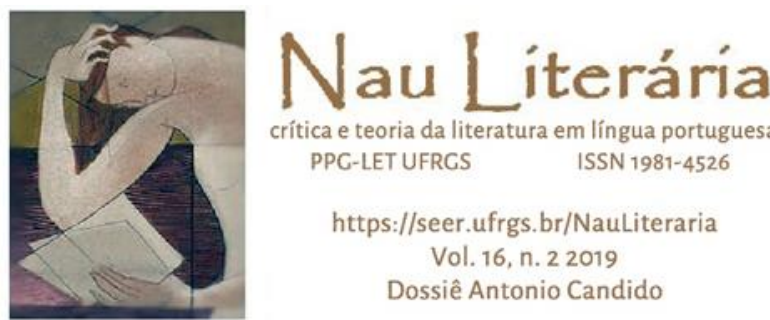

de Gramiro de Mattos - autor que se chamava Ramiro e acrescenta o G inicial e a preposição 'de' em homenagem ao poeta baiano - e Me segura q'eu vou dar um troço, de Wally Salormoon, cujo nome é Waly Salomão, modificado por "influência da palavra montagem joyceana" (SANTIAGO, 2000, p. 134). A modificação dos nomes denotaria o ímpeto revisionista dos poetas para corrigir as barbaridades que a organização dos acervos literários moldada pelos métodos históricos e dos estilos de época produz, segundo o crítico. Santiago, não em tom de objeção, lembra que Cândido, na Formação, sublinha a "inexistência de Gregório de Matos até o Romantismo", mesma defasagem da qual padecia Sousândrade, também reivindicado por Wally e Gramiro depois de recuperados pelos concretos. E, se com diz Santiago, Urubu Rei estaria para Macunaíma como Me segura que eu vou dar um troço pra as Memórias sentimentais de João Mirarmar, todos eles estariam, em alguma medida, voltados para o barroco, como se depreende do requisitado sistema de relações entre obras proposto.

Sobre uma produção consubstancial se debruça Charles Perrone, em artigo na Revista "Barroco", conduzida por Affonso Ávila a partir de 1969, ao sublinhar que o Tropicalismo possuía uma consciência histórica indicada, por sua vez, no verso de Torquato Neto da canção "Geléia Geral': ‘[...] santo barroco baiano [...]”. Isto, somado ao vasto uso de figuras que se contrastam, levam Perrone a concluir que "o sincretismo e a revisão estética essenciais ao projeto tropicalista incluem uma (re) apreciação dos fenômenos barrocos" (PERRONE, 1969 p. 337). Esta longínqua aproximação seria, também, proposta por Affonso Ávila, segundo o qual a "vida barroca" das Minas Gerais dos seiscentos era marcada pela presença do "êxtase festivo e de agonicidade existencial" (ÁVILA, 1971, p. 37) e, sua literatura, recheada de "letras e símbolos" não como unidades sintáticas de função linguística, mas "proposição plástica, de concepção não-verbal”, “pictórica”. O que levava, finalmente, Ávila a destinar a Gregório de Mattos a condição de precursor direto da Tropicália. (ÁVILA, 2971, p. 219)

Ao longo dos anos noventa e dois mil o barroco segue como dispositivo que une historiografia literária e pensamento acerca da cultura brasileira e latino americana como consta, por exemplo, em Pindorama revisitada, de Nicolau Sevcenko. Devido a uma preocupação histórica, o autor salienta que o Barroco não foi “estilo artístico passageiro", uma era, "mas substancia de síntese cultural", ou seja, uma "dimensão barroca" (SEVCENKO, 2000, p. 39). Para demonstrar isto, todavia, é à história que se recorre: Sevcenko sublinha que, no Brasil dos seiscentos, havia inúmeros movimentos sociais rebeldes anti-coloniais/escravistas 

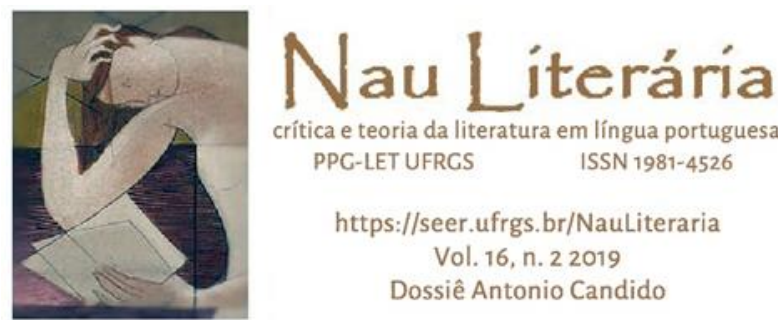

crítica e teoria da literatura em língua portuguesa

PPG-LET UFRCS ISSN 1981-4526

https://seer.ufrgs.br/NauLiteraria

Vol. 16, n. 22019

Dossiê Antonio Candido

que liberavam uma energia centrípeta e, daí a arte barroca: "instável, interativa, interpolada, dinâmica, mágica" que, a partir de uma crítica social, restitui a dimensão "dos impulsos afetivos" (SEVCENKO, 2000, p. 46) e da harmonia sensorial. Guardada as devidas diferenças, algo mais ou menos similar iria perquirir Irlemar Chiampi no seu estudo Barroco $e$ modernidade, no qual reúne artigos que publica sobre o tema desde os anos setenta até meados dos anos noventa. Logo no seu prefácio, a autora dissocia o "barroco como estrutura histórica ou estilo", prática, por sua vez, reacionária da Contrarreforma do século XVII, do "barroco moderno eterno e atemporal, que surge pra negar espírito clássico" (CHIAMPI, 2010, p. XVII). Todavia, a fim de explicar a origem de um barroco moderno luxuoso, calcado no prazer e na proliferação das linhas narrativas, a autora alega que o barroco surge como "pré-hegeliano, préburguês e pré-iluminista" e, talvez por isso, acaba sendo apropriado pela periferia do mundo apontando esta a uma ordem pós-burguesa? -, a América Latina, "que só recolheu as sobras da modernização, para rever o cânone historicista do moderno" (CHIAMPI, 2010, p. 19). Um exemplo? Gregório de Matos, cujo resgate "revela como esse cânone historicista do moderno, instaurado desde o romantismo, obscureceu as possibilidades de leitura do barroco" a partir das quais "o experimental e o lúdico" seriam reconhecidos "como selo de nossa diferença na produção da modernidade" (CHIAMPI, 2010, p. 21), finaliza a pesquisadora.

Como lembra Chiampi, "a pérola barroca saíra do seu ostracismo" ao ser recuperada pela vanguarda espanhola de 1927, quando Quevedo e Góngora são retomados, na ocasião do “Terceiro Centenário deste último" (CHIAMPI, 2010, p. 57), por poetas como García Lorca, Dámaso Alonso, Rafael Alberti, entre outros. Infere-se em Barroco e modernidade, todavia, ser no Brasil e em $\mathrm{Cuba}^{15}$ que tal reaproximação encontra uma fecundidade ímpar; curiosamente, são os dois últimos países do mundo a abolirem a escravidão ${ }^{16}$. Nicolau Sevcenko, em certa parte do seu estudo, perguntou-se: “(...) quem não reconhece o Brasil na fantasia do Barroco? Ou quem não reconhece o Barroco na fantasia do Brasil?” (SEVCENKO, 2000, p. 47). Parece, no entanto, que não estamos suficientemente seguros para afirmar do que se trata, exatamente, esta fantasia de Barroco - e, por consequência, a de Brasil? ${ }^{17}$.

\footnotetext{
${ }^{15} \mathrm{Na}$ ilha, a animada retomada do barroco se dá, especialmente, em três nomes, Alejo Carpentier, José Lezama Lima e Severo Sarduy - ainda que este tenha passado boa parte da vida na França.

${ }^{16}$ Esta lembrança me foi feito por Rodrigo Lopes de Barros na Boston University em 2017.

${ }^{17}$ A lista do percurso do barroco pela historiografia aqui apresentada, ao contrário do que se passa em Hansen (2004), é menos exaustiva que decisiva, especialmente diante dos propósitos específicos a este estudo. Caberia, neste sentido, duas outras menções, uma que sugere uma potente contemporaneidade ao barroco e, outra, que o
} 


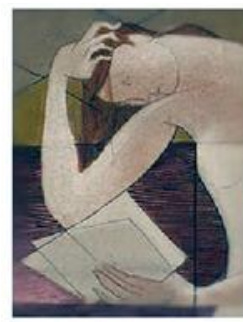

\section{Um elefante rosa}

Não interessa "negar a existência de 'barroco' nem propor que não se use o termo", afirma João Adolfo Hansen, afinal, "como dizia Deleuze” segundo o crítico, "é estranho negar a existência de 'barroco', como se negam unicórnios e elefantes rosa." (HANSEN, 2001, p. 14) Gilles Deleuze, então, ironizava a denegação radical “o Barroco não existiu” (DELEUZE, 1991, p. 64), a qual respondia, como se lê em A dobra: Leibniz e o barroco, de 1988, que, "se no caso de unicórnios e elefantes rosas (...) o conceito está dado" caberia, no caso do Barroco, "saber se se pode inventar um conceito capaz (ou não) de lhe dar existência." (DELEUZE, 2001, p. 64) Hansen acredita que não, e a prova desta impossibilidade seria o conceito já existente, a saber, o neo-kantianamente proposto por Heinrich Wõlfflin, origem das improcedentes qualificações do "barroco" elencadas pelo estudioso. Afinal, tal conceito é oriundo de atribuições teóricas que dispensam informações documentais e se colocam como esquema prévio, determinando o objeto segundo desígnios já estipulados. Por isso, “a noção apriorística ou dedutiva de 'barroco' é descartável, enfim, ainda que muitas de suas reencarnações até possam ser curiosamente folclóricas como o elefante rosa.” (HANSEN, 2001, p. 15)

Barroco, todavia, não estaria sozinho, afinal, poderíamos perguntar se Idade Média (existiu?) ou Modernidade (já somos ou fomos modernos?) não seriam, igualmente, folclores do século XIX e/ou XX. Sobre a provocação de Deleuze caberia, todavia, aproveitando o ensejo do insólito matizado pelo elefante rosa e lançar sobre ela o olhar proposto por Roberto Schwarz, ou seja, não somente se perguntar se barroco, assim como nacional ou elefante rosa, existe, i.e., se é um dado, mas tentar entender como ele funciona enquanto "processo e parte da cena contemporânea", enfim, como atua no presente. Giorgio Agamben certa vez escreveu que contemporâneo não é aquele que encara seu próprio século, mas aquele que, para fazê-lo, extravia-se "do seu próprio tempo"18 (AGAMBEN, 2009, p. 70-72) para colocá-lo em

resguarda ao contexto: neste caso, Gregório de Mattos e a Inquisição (1987), de Fernando da Rocha Peres; naquele, Uma literatura antropofágica (1982), de Lúcia Helena.

${ }^{18}$ Giorgio Agamben e o historiador da arte Georges Didi-Humerman têm despertado, especialmente a partir dos trabalhos de Walter Benjamin e do historiador Aby Warburg, uma função metodológica ao anacronismo. Neste ensejo, apenas ressaltamos que verificar como o outrora ressoa no agora, na contramão de uma ideia de saber e de tempo que o compreende enquanto retilíneo, progressivo e, portanto, irrepetível, homogêneo e vazio, não se presta somente a identificar sobrevivências, pontos de resistências, todavia, também como a barbárie persiste, ou seja, como a violência da norma - ou melhor, do Estado de exceção - se repete sob a diferença dos contextos. 

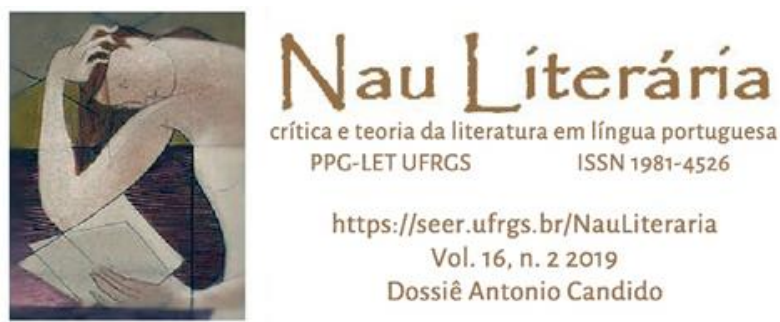

crítica e teoria da literatura em língua portuguesa

PPG-LET UFRCS ISSN 1981-4526

https://seer.ufrgs.br/NauLiteraria

Vol. 16, n. 22019

Dossiê Antonio Candido

perspectiva a partir de outras temporalidades, ou seja, de anacronismos. Hansen é consciente do problema, sobretudo quando pondera que "o passado é uma ficção do presente, ponto evanescente, mas não arbitrário de sua enunciação" (HANSEN, 2004 p. 50). Delimitação importante, uma vez que é justamente da mera arbitrariedade, do relativismo puro e simples, que se valem os revisionistas/negacionistas da escravidão, do Shoah ou das mudanças climáticas que assolam a Terra. Por isso, a questão que estamos tentando propor não é apesar do seu estudo, mas colocando-o no horizonte: o que poderia significar a formação de um imenso sistema, que percorre quase três séculos, a partir de um possível extravio de leitura ${ }^{19}$ ?

Numa das hipóteses, poder-se-ia constatar o íntimo parentesco entre erro e criação ${ }^{20}$, notando como um suposto mal-entendido teria nos legado um dos extratos mais valiosos e potentes de toda nossa literatura, e que mereceria o exame de cada caso. Noutra, resta um imenso assombro, uma incômoda perplexidade diante da permanência de um erro que repetiria, como num ato falho ${ }^{21}$, o Regime Antigo ali mesmo quando designa uma ordem pós-burguesa,

\footnotetext{
${ }^{19}$ A variação completa de um objeto dependendo da leitura que dele se faz não é um fato isolado na literatura brasileira. Veja-se alguns casos diretamente implicados na série barroca: Macunaíma que, outrora lido como uma insubmissão pelo descaráter, como mostrado, em recente leitura de Carlos Berriel (2013; 1987) é, ao contrário, postulado verificação da possiblidade de existência da identidade nacional que se forma, por sua vez, a partir da união das três raças, sendo a busca pelo seu amuleto, roubado por um industrial italiano, logo, símbolo da cultura global, de empréstimo, coloca em jogo a possibilidade da existência de tal identidade cultural matizada pelo amuleto. Ou seja, um olhar neo-romântico da perspectiva do Regime Antigo, qual seja, a aristocracia cafeicultora de São Paulo - e, por isso, o fatídico poema "Ode ao burguês", de Mário de Andrade, não como evocação, portanto, de uma ordem pós-burguesa. Poderíamos também mencionar Os sertões, de Euclides da Cunha, incluído por Haroldo de Campos na série de escritores difíceis, cujo precursor é Antônio Vieira. Enquanto Walnice Nogueira Galvão (2009) vê a compaixão pelo sertanejo como pedra no sapato das teorias raciais de Euclides, engendrando um paradoxo patológico e textualmente rico, além da intertextualidade com a Bíblia e outros movimentos que garantiriam sua participação no cânone; Luiz Costa Lima (1997), ao contrário, nota que o entusiasmo pelo sertanejo se dava pois era um mestiço incubado no interior do sertão e, por isso, livre a mestiçagem contínua, como se passava com os neurastênicos do litoral. Ou seja, neo-romanticamente o sertanejo seria uma raça pura brasileira. Logo, o sertanejo ser, antes de tudo, um forte, seria uma extensão das teorias raciais. Finalmente, Memórias de um sargento de milícias. Em sua leitura, que se coloca como continuadora da realizada por Cândido e Schwarz, Edu Otsuka (2007; 2016) objeta que, na verdade, a oscilação entre ordem e desordem seria, antes, a existência de um espírito rixoso, ou seja, "a lógica da vingança comandando a ação das personagens" (OTSUKA, 2016, p. 62). A questão é que a competição é nada mais que a incorporação dos valores dominantes, ou seja, uma outra forma de os de baixo se submeterem à norma hegemônica uns aos outros.

${ }^{20}$ Diante de uma origem irrecuperável, Michel Foucault, a partir de Nietzsche, propõe um trabalho com a noção da história para o qual interessa menos estabelecê-la que verificar as condições sob as quais um determinado discurso se tornou dominante, ou seja, fazer uma história da história ( $C f$. FOUCAULT, 1979). Poder-se-ia especular se não é justamente por manter uma violência, que acaba sendo dissimulada e perpetuada por uma idealização da cultura brasileira como pacífica, "malandra", tolerante, que a leitura animada com o barroco trinfou. ${ }^{21}$ Caberia indagar se, caso o barroco esteja repondo um lugar talvez até mais violento que o do "índio filho de Maria" romântico, Haroldo de Campos, ao tentar fugir da lei do pai, seja ela o Romantismo ou a crítica que o adota como esquema, não acabaria sucumbindo à sua lei? Isto teria de ser examinado bem de perto. Todavia, alertamos que nem tudo se passou num nível inconsciente e, o papel fundacional do barroco, ou seja, sua retomada enquanto parte de uma Bildung, por exemplo - neste sentido, tornar-se-ia bastante pertinente a inferêcia de Hansen quando
} 



PPG-LET UFRCS ISSN 1981-4526

https://seer.ufrgs.br/NauLiteraria

Vol. 16, n. 22019

Dossiê Antonio Candido

mais aberta. Se assim for, na mesma imagem na qual nos enxergávamos como insubmissos malandros, como num trompe l'oeil barroco, não passávamos, na verdade, de pícaros servis, que alguma brutalidade da vida que não conseguimos divisar muito bem tornou um tanto ingênuos, fantasiosos sobre o que somos: incapazes, enfim, de elaborar a própria história.

Pois entre aproximar a poesia atribuída a Gregório de Matos de nós ou simplesmente recusar toda e qualquer vizinhança, a tentativa de lidar com a tradição que dela é oriunda, ainda que por um suposto extravio, abriria uma outra possibilidade: que o barroco continuaria perfeitamente contemporâneo de um povo que sempre se projetou alegre e aberto, mesmo estando num dos países onde mais se mata mulheres, negros e LGBTQI+ no mundo.

\section{REFERÊNCIAS}

AGAMBEN, Giorgio. O que é o contemporâneo? e outros ensaios. Tradução Vinícius Nicastro Honesko. Chapecó: Argos, 2009.

ANDRADE, Mário de. Macunaíma. O herói sem nenhum caráter. Edição crítica. Coordenadora: Telê Porto Ancona Lopez. Edição simultânea. Impresso pela Editora da UFSC: Florianópolis, 1988.

ANDRADE, Oswald. “A sátira na Literatura Brasileira.” In: Estética e política. Pesquisam organização, introdução e estabelecimento de texto por Maria Eugênia Boaventura. São Paulo: Globo, 1994.

A utopia antropofágica. São Paulo: Globo, 1995.

Primeiro caderno do aluno de poesia Oswald de Andrade. São Paulo: Globo, 2005.

aponta um caráter nacionalista em $O$ sequestro... -, não é algo que seus proponentes escondem. Vejamos: $O$ sequestro do barroco foi publicado no fim dos anos oitenta, ou seja, já na autodeclarada fase "pós-utópica" de Campos. Porém, a retomada do barroco tem uma de suas primeiras reivindicações em 1960, no texto "Contexto de uma vanguarda", no qual se elogia a construção de Brasília sob a insígnia da sincronia renovadora e atualizadora da tradição pela modernidade, vislumbrando curiosas ressonâncias entre as fórmulas arredondadas do barroco sim, o adjetivo é retirado direto de Renascença e barroco (1888), de Heinrich Wofflin (2010, p. 45), o ponto neokantiano que inventa o barroco, segundo Hansen - e as construções da nova capital: "da arte atualíssima de Niemeyer, disse Lúcio Costa, o urbanista de Brasília, sem temer o aparente paradoxo, que era que mais lhe trazia a evocação da arquitetura barroca do Aleijadinho. A tradição viva é moderna.” (CAMPOS, 2006, p. 213). Ora, estamos aqui somente dois anos após o "Plano piloto para a poesia concreta", publicado pelos irmãos Campos junto a Décio Pignatari no quarto número da "Revista Noigrandes", bastante racionalista e entusiasta da indústria, e apenas um ano após a publicação da Formação da literatura brasileira, por Antônio Cândido. Tal reivindicação, portanto, pode perfeitamente entendida como uma Bildung alternativa àquela da USP, com sua própria paideuma. 

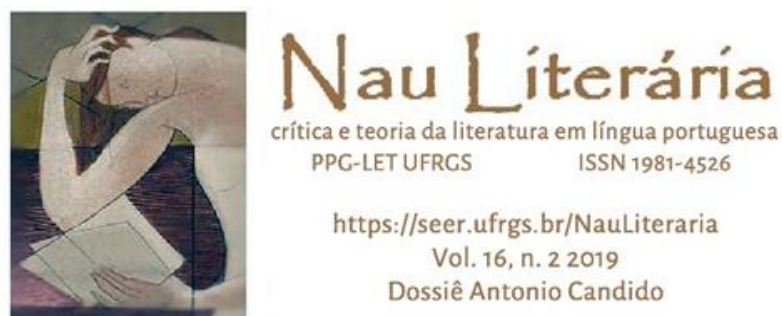

ARARIPE JÚNIOR, T.A. Gregório de Mattos. Rio de Janeiro/Paris: Garnier, 1910.

ARISTÓTELES. A politica. Tradução: Roberto Leal Ferreira. $3^{\circ}$ edição. São Paulo: Martins Fontes, 2006.

ÁVILA, Affonso. O lúdico e as projeções do mundo barroco. São Paulo: Perspectiva, 1971.

BERRIEL, Carlos. Tietê, Tejo e Sena: a obra de Paulo Prado. Campinas: Editora da Unicamp, 2013.

Dimensões de Macunaíma: filosofia, gênero e época. Tese apresentada ao Departamento de Teoria Literária do Instituto de Estudos da Linguagem da Universidade Estadual de Campinas para obtenção do título de mestre. Orientador: Prof. Dr. Roberto Shwarz. Campinas, 1987.

BOSI, Alfredo. História concisa da literatura brasileira. Cultrix. SP. 1975.

Dialética da colonização. São Paulo: Companhia das Letras, 1992.

BOURDIEU, Pierre. As regras da arte: gênese e estrutura do campo literário. Trad. Maria Lúcia Machado. São Paulo: Companhia das Letras, 1996.

CAMPOS, Augusto de. "Revistas re-vistas: os antropófagos". In: Poesia, antipoesia, antropofagia. São Paulo: Editora Cortez \& Moraes, 1978.

CAMPOS, Haroldo de. "Da razão antropofágica: diálogo e diferença na cultura brasileira". In: Metalinguagem e outras metas: ensaios de teoria e crítica. 4. ed. São Paulo: Perspectiva, 2010. O sequestro do barroco na Formação da literatura brasileira: o caso Gregório de Mattos. Salvador: Fundação Casa de Jorge Amado, 1989.

“Uma leminskíada barrocodélica". In: Metalinguagem e outras metas: ensaios de teoria e crítica literária. São Paulo: Perspectiva, 2010.

CÂNDIDO, Antônio. Formação da literatura brasileira. Momentos decisivos 1750-1880. Rio de Janeiro: Ouro sobre azul, 2009.

"Letras e ideais no período colonial". Literatura e sociedade. Estudos de teoria e história literária. Ri de Janeiro: Ouro sobre Azul, 2010.

“Dialética da malandragem". In: O discurso e a cidade. Rio de Janeiro: Ouro sobre azul, 2010. (1970)

CHOCIAY, Rogério. Os metros do boca: teoria do verso em Gregório de Matos. São Paulo: UNESP, 1993.

CHIAMPI, Irlemar. Barroco e modernidade. São Paulo: Perspectiva, 1998. 


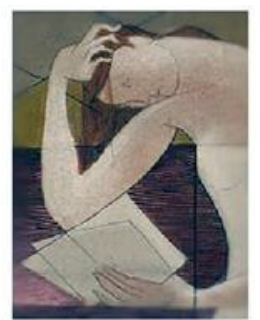

FANON, Frantz. Os condenados da terra. Rio de Janeiro: Civilização Brasileira, 1968. . Pele negra, máscaras brancas. Salvador: EdUfba, 2008.

FOUCAULT, Michel. Microfísica do poder. Organização e tradução de Roberto Machado. Rio de Janeiro: Edições Graal, 1979.

GALVÃO, Walnice Nogueira. Euclidiana. ensaios sobre Euclides da Cunha. São Paulo: Companhia das letras, 2009.

HANSEN, João Adolfo. A sátira e o engenho. Gregório de Matos e a Bahia do século XVII. São Paulo: Ateliê Editorial; Campinas: Editora da Unicamp, 2004. . "Barroco, neobarroco e outras ruínas." Teresa. (12-13), 50-64, 2013. . "Romantismo e barroco." Teresa. (2), 10-67, 2001. . "Esquema para Vieira”. In: Nenhum Brasil existe. Pequena enciclopédia. Rio de Janeiro: UniverCidade Editora, 2003. . O o da ficção da literatura em Grande sertão: veredas. São Paulo: Hedra, 2000.

HELENA, Lucia. Uma literatura antropofágica. Ceará: Universidade Federal do Ceará, 1983. HOBSBAWM, Eric. A invenção das tradições. Rio de Janeiro: Paz e Terra, 1997.

HOUAISS, Antônio. “Tradição e problemática em Gregório de Matos”. In: AMADO, James (org.). Obras completas de Gregorio de Mattos e Guerra. (Crônica do viver baiana seiscentista). Salvador, Janaína: 1968.

LEMINSKI, Paulo. Catatau. Porto Alegre. $2^{\circ}$ Edição: Sulina, 1989.

LIMA, Luiz Costa. Terra ignota: a construção de "Os Sertões". Rio de Janeiro: civilização brasileira, 1997.

MACHADO, Roberto. O nascimento do trágico. De Schiller a Nietzsche. Rio de Janeiro: Jorge Zahar, 2006.

PERES, Fernando da Rocha. Gregório de Mattos e a inquisição. Salvador, Centro de Estudos Baianos da UFBA, 1983.

PROENÇA, M. Cavalcanti. Trilhas no Grande Sertão. Rio de Janeiro: Departamento de Imprensa Nacional, 1958.

NICODEMO, Thiago Lima. "Subsídios para o estudo das relações intelectuais entre Antônio Candido e Sérgio Buarque.” In: Carvalho, Fábio de Almeida; Eugênio, João Kennedy. (Org.). Interpretações do Brasil. Rio de Janeiro: E-papers, 2014. 

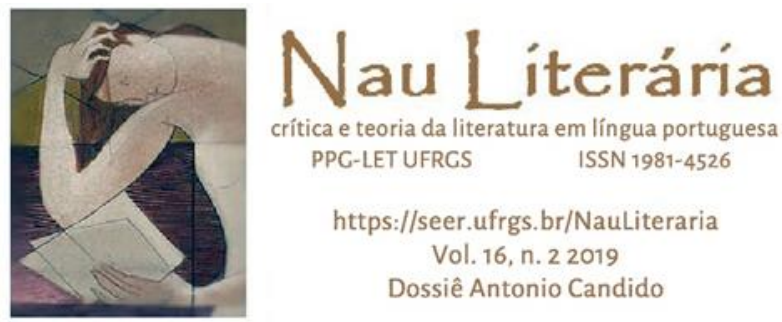

NOGUEIRA, Erich Soares. “A voz indígena em 'Meu tio o irauaretê', de Guimarães Rosa”. Nau Literária: crítica e teoria de literaturas. Dossiê: Voz e Interculturalidades. Volume 9, número 1. Porto Alegre: janeiro/junho de 2013.

RAMOS, Nuno. Ó. $3^{\circ}$ reimpressão. São Paulo: Iluminuras, 2008.

ROSA, João Guimarães. "Meu tio o Iauaretê”. Estas histórias. $5^{\circ}$ edição. Rio de Janeiro: Nova Fronteira, 2001.

OTSUKA, Edu Teruki. Era no tempo do Rei. Atualidade das Memórias de um sargento de milícias. São Paulo: Ateliê Editorial, 2016.

. "Espírito rixoso: para uma reinterpretação das Memórias de um Sargento de milícias".

In: Revista do IEB, São Paulo: 44: 105-124, fev. 2007.

REGO, Enylton de Sá. O calundu e a panaceia. A sátira menipéia e a tradição luciânica. Rio de Janeiro: Forense, 1989.

ROMERO, Silvio. História da literatura brasileira. Tomo segundo. Formação e desenvolvimento da literatura nacional. $6^{\text {a }}$ edição. Organizada e prefaciada por Nelson Romero. Rio de Janeiro: José Olympio, 1960.

SANTIAGO, Silviano. “Os abutres”. In: Uma literatura nos trópicos. Rio de Janeiro: Rocco, 2000 .

SARAIVA, Antônio J. O discurso engenhoso. Estudos sobre Vieira e outros autores. São Paulo: Editora Perspectiva, 1980.

SEVCENKO, Nicolau. Pindorama revisitada. Cultura e sociedade em tempos de virada. São Paulo: Peirópolis, 2000.

SCHWARZ, Roberto. “Cultura e política, 1964-1969.”. In: Ao vencedor as batatas. São Paulo: Ed. 34, 2008.

"O sentido histórico da crueldade em Machado de Assis". Novos Estudos CEBRAP, 17, 1987.

"Pressupostos, salvo engano, de 'Dialética da malandragem”. In: Que horas são? São

Paulo: Companhia das Letras, 1987.

SUSSEKIND, Flora. Papéis colados. Rio de Janeiro, Editora da UFRJ, 1993.

VELOSO, Caetano. “Triste Bahia”. In: Transa, 1972.

VERÍSSIMO, José. História da literatura brasileira. De Bento Teixeira (1601) a Machado de Assis (1908). 3ª Edição. Rio de Janeiro: José Olympio, 1954. 




Nau

PPC-LET UFRCS ISSN 1981-4526

https://seer.ufrgs.br/NauLiteraria

Vol. 16, n. 22019

Dossiê Antonio Candido

WÖLFFLIN, Heinrich. Renascença e barroco. Tradução: Mary Amazonas Leite de Barros e Antonio Steffen. São Paulo: Perspectiva, 2010 